Afric

ArXiv

Article title: MULTICULTURAL EDUCATION DESIGN

\title{
BASED ON DOING GOOD ACCORDING TO THE OLD TESTAMENT
}

Authors: davidming ming[1]

Affiliations: BANDUNG THEOLOGICAL SEMINARY Soekarno Hatta 399[1]

Orcid ids: 0000-0001-9649-1622[1]

Contact e-mail: restorasisttinjili@gmail.com

License information: This work has been published open access under Creative Commons Attribution License http://creativecommons.org/licenses/by/4.0/, which permits unrestricted use, distribution, and reproduction in any medium, provided the original work is properly cited. Conditions, terms of use and publishing policy can be found at https://www.scienceopen.com/.

Preprint statement: This article is a preprint and has not been peer-reviewed, under consideration and submitted to AfricArXiv Preprints for open peer review.

Links to data: https://www.researchgate.net/publication/319046894_Login

DOI: $10.14293 / 111.000 / 000014 . v 1$

Preprint first posted online: 13 January 2021 


\title{
MULTICULTURAL EDUCATION DESIGN BASED ON "DOING GOOD” ACCORDING TO THE OLD TESTAMENT
}

\author{
GP Harianto ${ }^{1 *}$, David Ming ${ }^{2}$ \\ ${ }^{1}$ Sekolah Tinggi Teologi Excelsius Surabaya, Indonesia \\ ${ }^{2}$ Sekolah Tinggi Agama Kristen Anak Bangsa \\ *hariantogp@stt.excelsius.ac.id
}

Abstract: Doing good is universal in which all people with various religious, ethnic and other backgrounds must be happy to do good. The problems that arise in the question are as follows: What are the values of doing good according to the Bible? What is the challenge of "doing good" according to the dimensions of Multicultural Theology? How is the implementation of Multicultural Theology education about doing good into Christian ministry? The answer is: (1) Good deeds are commands given by God to His people. If a human being wants to be said to be good, he is obliged to do good. Because good deeds have a universal character. (2) The challenge of "doing good" in the dimension of multicultural theology is: the challenge of "doing good" in theocentric, the challenge of "doing good" in Christocentric (the principle of the Incarnation, the principle of salvation, the principle of the Holy Spirit, and the principle of the Naturality of the Church) and (2) the challenge "Doing Good" from Theocentric to Christocentric ".

(3) Multicultural theology regarding "doing good" becomes a very influential implementation to lead someone to enter the concept of theocracy which is then sharpened to Christocentric. Here the value of the Great Commission of Jesus Christ to win people becomes real and can be implemented properly. But, of course, the work of the Holy Spirit in the believer is critical to the success of the Great Commission mission.

Keywords: multicultural theology, good deeds, education, service

\section{INTRODUCTION}

The word "do good" means to do (do) something: good; worth; orderly (neat, neat, flawless), not evil (behavior, manners, lineage, etc.); honest; good; virtue: a virtuous heart; to fellow human beings. ${ }^{1}$

Doing good is universal where all people with various religious, ethnic and other backgrounds are sure to be happy to do good. In fact, if they do not do good (do evil) it will be labeled as "people who break the law" and some even call "cursed" people who do evil. For example, "the bombings that occurred in New York, Bali and in other countries of the world, so everyone says" damned them ". They are cursed by the eyes of the world. Likewise, people who burn places of worship have done "accursed them". All eyes of the world condemn them regardless of ethnic or religious background.

1"Baik"; KBBI. Versi 1.1. CD-Rom. 
Surely everyone can accept and enjoy seeing humans can do good. People even say that doing good has the following consequences: (1) He is liked by people. (2) He is appreciated by people. (3) He is needed by people. (4) He is a living example for others. In this regard, the research results of the Faculty of Psychology of The University of Michigan, USA, some time ago, showed that doing good actually prolongs life! A person who does good deeds will have a calm heart. People whose hearts are calm, good hormones in their bodies will develop. Formed a healthy body. Such is the simple relationship. Starting from inner satisfaction, one's physical health can be formed. This is a gift that has no value and every human being should do it as well as possible. Doing good can be done in any way. Smiling, making way for someone who is in a hurry, or saying thank you are all simple ways of doing good. It can be done by anyone. Is it difficult to greet, greet and receive people with a friendly smile? What trouble is there to treat everyone with love, generosity and respect? ${ }^{2}$

A study conducted by the University of British Columbia found that the effect of doing good to others reduced the depression that was being experienced. ${ }^{3}$ Furthermore, it is said that when he does good deeds consciously, his brain opens and there is a flow of universal energy to him. All body organs work normally. Even better. 70 percent of the body consists of water. According to Masaru Emoto's research, water has a high recording power. When doing good means that human body fluids record virtue. And the result is normal mind and body and even optimal performance. This, supported by a researcher who is also a Japanese, Hiromi Shinya, conducted research on the benefits of enzymes. The conclusion is also very similar to Masaru Emoto's research results. Good thoughts and always being grateful result in enzyme production running well. Enzym is a substance in the form of a liquid that really helps the body's metabolism. It was Shigeo Haruyama who proved the magic of endorphins. In his research it was proven that pure good thoughts will produce beta endorphins which have an effect on improving health for the human body. ${ }^{4}$

\section{METHOD RESEARCH}

The writer used library research aims to find the following answers: What are the values of doing good according to the Bible? What is the challenge of "doing good" according to the dimensions of Multicultural Theology? How is the implementation of Multicultural Theology education about doing good into Christian ministry?

\footnotetext{
2“"Berbuat Baik Setiap Hari”; http://kolom.abatasa.co.id/kolom/detail/motivation/672/berbuat-baiksetiap-hari.html (Diakses 20 April 2014).

3 "berbuat Baik Bisa redakan Despresi"; http://palingseru.com/19943/berbuat-baik-bisa-redakan-depresi (Diakses 20 April 2014).

4 "Pengadilan Tuhan Tidak Mesti Menunggu Kiamat..."; http://hiburan.kompasiana.com/humor/2013/11/26/pengadilan-tuhan-tidak-mesti-menunggu-saat-kiamat614222.html (Diakses 14 April 2014).
} 


\section{RESULT AND DISCUSSION}

\section{Values Doing Good}

\section{The Meaning of "Doing Good"}

In Kamus Besar Bahasa Indonesia that good has several meanings as follows: (1) elok; worth; regular (neat, tidy, no pants, etc.). (2) upright; lucky (tt fate); profitable (tt position etc.). (3) useful; effective (tt medicine etc.). (4) not evil (tt conduct, character, descent, etc.); honest. (5) recover; recovered (tt wounds, damaged items, etc.). (6) safe (nothing less). (7) as appropriate; is supposed. (8) (to state) somehow ... somehow. (9) yes (to say yes). (10) goodness; virtue: a virtuous heart. ${ }^{5}$

More specifically, "Kindness" (Hebrew tov) refers to something that is pleasant, joyful or friendly. Something that gives happiness or satisfaction that results in aesthetic or moral satisfaction. The LXX translates tov as "agathos", the usual Greek word for describing a good idea as a physical or moral quality, and sometimes translating it as kalos (literally 'beautiful'; so both in classical Greek and in the Bible, good works are called actions that are "noble" "" honorable "," admirable "and" worthy "of praise". 6

\section{Good deeds are Processes}

Good deeds are a process and can not be done once in human life but continuously actively. In Genesis 4: 7 it reads: "If you do not do well, will your face not be radiant? But if thou doest not well, sin lieth at the door; it tempts you, but you have power over it. "The word" do good "in Hebrew יטיטיב is the means" to be good. "But what is interesting verb hiphil imperfect 2nd person masculine singular, meaning" do good "directly -continued, a reflective process that becomes good.So "doing good" is a process done by a person to be better. On the contrary, if he does not do the process of being good or doing evil (Job 24:21; Ps. 14: 3; 36: 3), then he is a sinner. The text above emphasizes that one must choose to do good is pleasing to God and to do evil is sin.In fact God himself does good (Ex. 1:20; Judg.17: 13). (1 Sam. 25:31) God did this because "Indeed, there is no god on earth: who does good and never sins!" (Eccl. 7:20).

Further in the PBS it is said: "Let us not be weary in well doing" (Gal. 6: 9; Titus 6:18; Jas. 4:17), therefore, as long as we have the opportunity, let us do good. good to all, but especially to our fellow believers (Gal. 6:10), and in Hebrews 13:16 it says: "Do not forget the doing of good and the sharing of things with others, for with such sacrifices God is well pleased." .

\footnotetext{
5“'Baik". KBBI Offline 1.3.CD-ROM.

${ }^{6}$ Baik; kebaiakan"; Ensiklopedia SABDA; http://alkitab.sabda.org/dictionary.php?word=BAIK,\%20KEBAIKAN (Diakses 14 April 2014). Dalam ensiklopedia tersebut dikatakan bahwa dalam PB mengembangkan pemakaian kata ini dengan menggunakan kedua kata sifat di atas secara bergantian (bnd mis Rm. 7:12-21). Paulus, mengikuti LXX, menggunakan kata benda agathosyne untuk menggambarkan kebaikan Kristen, dengan penekanan utama pada kemurahan hati (Rm. 15:14; Gal. 5:22; Ef. 5:9; 2 Tes. 1:11; mengenai terjemahannya, lih tafsiran kitab-kitab ini). la juga memakai kata chrestotes ("kebaikan", "kemurahan") untuk kemurahan hati Allah yg mengasihani (Rm. 2:4; 11:22).
} 


\section{Elements of Doing Good}

The element of doing good is "pleasing before God". The word "please" refers to the value contained by something. Examples are "useful", such as salt (Matt. 5:13; Luke 14:34), "high quality" such as gold (Gen. 2:12), "livestock" (Gen. 41:26), "productive" like a tree (Matt. 7:17), "earth" (Luke 8: 8). But the biblical understanding of moral and spiritual goodness is truly theological, and is in stark contrast to the (anthropocentric) human-centered view of goodness developed by the Greeks and their later philosophers. The meaning of the Bible can be described as follows: (1) God is good, because morally He is perfect and sublime in generosity. The recognition that God is good is the basis of all biblical thinking about moral goodness. The word "Good" in the Bible is not an abstract quality, nor is it a secular human ideal; "Good" first and foremost means what God is ("He is good", Ps. 100: 5). (2) God's deeds are good, because His deeds express the attributes of His wisdom and power (Ps. 104: 24-31), and are pleasing to Him. When the act of creation was completed, "God saw everything He had made, and it was very good" - wetob (Gen. 1:31; cf. vv. 4, 10, 12, 18, 21, 25). (3) The gifts of God are good, because the gifts reveal His generosity, and are destined for the well-being and safety of the recipient. Words like "Useful", "useful", "profitable" are some of the secular meanings of "good" as an adjective, while "prosperity" and "well-being" are nouns. The Bible combines both in its theology by teaching that not only are all gifts of God good both in purpose and in effects, but also that all that is good is in fact the gift of God (James 1:17; Ps. 4: 6). (5) Obedience to God's commandments is good, because God is pleased and accepts it (1Tim. 2: 3), and those who do it will benefit from it (Titus 3: 8). ${ }^{7}$

\section{Consequences of Doing Good}

"Doing good" is not just a command from God but when a person does good, then he will result in the following: God bless (Gen. 26:29), making your descendants as the sand of the sea, which in abundance is innumerable (Gen. 32: 1). 12), God does good to our lives (Num. 10:29). God bless (Deut. 28:63; Jer. 32:41), your children will sit on the throne of Israel until the fourth generation (2Ki. 10:30), be calm (Ps. 116: 7), the righteous surround it. (Ps. 142: 7), I want to sing to the Lord (Ps. 13: 6), praise Your name (Ps. 142: 7), do good to oneself (Prov. 11:17), and he fears God (Jer. 32:40).

Doing good is not because you are bribed but it is obligatory to do it (Num. 24:13) because God teaches and sets an example for someone to do good (Deut. 8:16). If a person does good then it results in that others also do good to him (U1.30: 5).

\section{The challenge of "doing good" in the Multicultural Theological Dimension}

The Challenge of "Doing Good" in Theocentric

God's general statement is present for all people. The general statement is the act of God expressing Himself through the universe, history, and human conscience. God is something that is worshiped by human beings. God has revealed Himself to man in full. It can be seen from the names that God has. God's name is always used in conjunction with

\footnotetext{
${ }^{7}$ Baik; kebaiakan"; Ensiklopedia SABDA; http://alkitab.sabda.org/dictionary.php?word=BAIK,\%20KEBAIKAN (Diakses 14 April 2014).
} 
perfection such as faithfulness (Isa. 49: 9), grace (Ps. 23: 3), glory (Ps. 79: 9). The names of God have authoritative information about the attributes, thoughts or designs of God.

While human nature is those who are enjoying daily life, working, exercising, vacationing, going to school, and so on. Here that human nature in Genesis 1: 26-27, explains that man was created according to the "image" and "image" of God. The words "image" and "appearance" do not indicate two different things, but contain similarities. This similarity emphasizes the divine similarity - not physical similarity - between God and His creation, namely: man. But, because man fell into sin, then this divine equality is broken. ${ }^{8}$

In connection with the above, the challenge of "doing good" in Theocentric (general) is a cultural mandate (given by God to all humans - shared stewardship and shared responsibility), Human Nature (humans as in the image of God - Imago Dei and Similitude Dei), God's sovereignty (humans are part of their will to achieve eternal goals), God's Providence (every human being has the right to live as provided by God), God's justice (as God's judge holds accountable for what humans have done. God wants humans to be fair to everyone according to what is their right), the holiness of God (every believer has a responsibility to present God's holiness among other people who are of different ethnicity and religion). ${ }^{9}$

Allah is everything. By knowing God the deeper it means that man knows himself. For all things originate and are in God, and he is in him. All life exists in and from Allah, whether it is the lowest unconscious form of life or the supreme life which is very intelligent and selfaware.

And what do humans need to know about Allah? None other than His divine nature, His existence, His eternity, His infinity, His immutability, His omniscience, His wisdom, His omnipotence, His supremacy, His faithfulness, His goodness, His justice. Him, His mercy, His grace, His holiness, His sovereignty, and much more. However, because of God's perfection, sinful humans cannot see and know God perfectly either. Even for those who do not believe in Him, it is difficult to see God's personality. Here, God hopes that all people on this earth believe in Him but they refuse. Therefore, the key to knowing His person, in those who believe in Him. In what ways do those who believe in Him see the person of God? Nothing else, with faith and love we can see Him at a glance. ${ }^{10}$

So the challenge of "doing good" is carried out by someone (human) with other humans regardless of their religious or ethnic, economic, social and other backgrounds. All human beings have the same position as humans created by Allah and they, with each other, have the right to do good to one another, help each other and live hand in hand together on earth.

\section{The "Doing Good" Challenge in Christocentric}

God's special statement is for people who believe the Bible as God's Word. Specific statements are revelations given by God through the redemptive work of Jesus Christ in

\footnotetext{
${ }^{8}$ Elohim (Allah) menciptakan manusia dalam gambar-Nya seperti ayat 26. Dalam hal ini, Gambar dan rupa Allah dikaitkan dengan hakekat manusia. Dalam manusia seperti inilah Allah menghembuskan nafas hidup (Kej. 2:7). Dengan demikian, manusia memiliki sebagai berikut: (1) Norma moral. (2) Kesadaran akan kematian dan kemungkinan adanya kehidupan setelah mati. (3) Kesadaran akan adanya kodrat yang lebih tinggi. (4) Kemampuan untuk mengungkapkan kebenaran yang mutlak atau yang paling dasar.

${ }^{9}$ G. Sudarmanto, Teologi Multikultural (Batu: YPPII, 2014) 101-123.

${ }^{10}$ A. W. Tozer, Mengenal yang Mahakudus (Bandung: Kalam Kudus, t.t.) 40.
} 
history, and these revelations are found only in the Bible. For example: someone is saved because they believe in Jesus, gets the Holy Spirit every day, the Holy Spirit lives in us, gets the kingdom of God, the promise of forgiveness, the promise of blessings, and so on.

In the context of God's special revelation (in the life of a believer), the challenge for believers to "do good" towards others must be done. The challenge of "doing good" in Christocentric (Christianity) is incarnation (God became man to show solidarity and selfidentification), universality Soteriology (Jesus as Savior for all who accept Him as their Savior), Theocracy-Presentist refers to the present (Christ rules according to has the power to regulate His creation), the universality of the Work of the Holy Spirit (the Holy Spirit does everything according to the commandments of Christ), the naturality of the church (the Church as the body of Christ is the church to be creative in serving in the midst of the world) and multicultural eternity (the Church will continue into eternity). ${ }^{11}$

\section{The Principle of the Incarnation}

This point of "doing good" between believers begins with Jesus' incarnation on earth. It started after the first human Adam and Eve fell into sin, causing all of his descendants to sin. All humans are not righteous, not even one (Rom. 3:10). All humans have sinned and fall short of the glory of God (Rom. 3:23). And the reward is death (Rom. 6:23). Because man has sinned, the relationship between God and man is cut off, man cannot reach God. Everything that humans do to achieve salvation is futile, whether it is by doing good deeds or by doing good deeds, because all human good deeds are only dirty rags before God (Isaiah 64: 6).

After all the means previously used to obtain salvation were in vain, at last the Savior Himself came. God knows that it is impossible for humans to gain salvation by their own efforts, because no one is perfect.

\section{Principles of Safety}

God's good works are manifested through God's love in a way that is revealed through His Son so that humans may live (1 Jn 4: 9), but God showed His love for humans through Christ's death on the cross when we were still sinners (Rom. 5: 8) ). This is because God's love for humans is so great, even though people always live against God (John 3:16). Even the basis of God saving mankind is love. Psalm 33: 5b says that the nature of God's love is faithful, it does not leave loved ones. He still loves humans even though we often don't love God.

Love is a gift (gift) of God to humans. It is said to be a gift, because humans do not pay back God's love (John 3:16). The problem is: how do humans respond to God's love? Humans must keep His commandments. The form of love must be manifested in everyday human actions. However, humans often experience the obstacle that humans cannot love their enemies while God can love humans who rebel against Him. The implication of love for humans is that humans must live "doing good" to God and others.

What Jesus gave to man, namely salvation can be obtained by man through the way of grace. Through the Holy Spirit, God attracts and invites people to Jesus Christ and repentance. Then God led the man to the choice to decide his will, whether he would repent and welcome the Lord Jesus as his Savior. Likewise the final choice must be from the human will. God wills that all people do not perish (2 Pet. 3: 9).

\footnotetext{
${ }^{11}$ Ibid. 124-152.
} 


\section{The Principle of the Holy Spirit}

In this context, the Holy Spirit has a role to replace Jesus Christ after Jesus rose to heaven. Why did the Lord Jesus have to go (John 16: 7-11)? As long as the Lord Jesus is still in the world, the Holy Spirit cannot come. The Holy Spirit as a substitute for the Lord Jesus comes as our helper and will accompany us forever. The Holy Spirit is present in the believer, not present in the unbeliever.

The Holy Spirit as a dynamic in mission work. The Holy Spirit is mentioned more than 250 times in the New Testament. ${ }^{12}$ The Holy Spirit in Greek "parakletos" means "as a comforter". In the passive form it means "one who is called aside" to help. Basic word forms of the words "parakalein" and "parakletoi". "Parakalein" is used especially to encourage people, to encourage them to produce right actions and noble thoughts. The word "parakalein" is used in connection with fighting. "Parakletoi" or pushers were veterans who pushed soldiers before and during meetings. ${ }^{13}$

"Parakletos" has a Septuagint background that expresses a kind of serenity and consolation in suffering that keeps a person standing on his feet, which if the person is left alone, he will fall. It is this serenity that allows one to go through critical moments and not fall. ${ }^{14}$

"The Comforter, which is the Holy Ghost, whom the Father will send in my name, he shall teach you all things, and bring all things to your remembrance, whatsoever I have said unto you "(John 14:26).

"But ye shall receive power, after that the Holy Ghost is come upon you: and ye shall be witnesses unto me both in Jerusalem, and in all Judaea, and in Samaria, and unto the uttermost part of the earth" (Acts 1: 8).

Thus, the function of the Holy Spirit is: (1) not only to realize, but also to move people to do something and bring people to Christ. The Holy Spirit realizes sin constantly. Sin here means having a "disease" and not managing his "disease", not trying to recover from his "disease". For example: stealing, adultery, envy, slander, and more. It means that sin remains in an act that is not pleasing to God. The Holy Spirit convicts man of his sins until he becomes a new human being. (2) The Holy Spirit realizes the truth that Jesus went to the Father and man no longer sees Him. At that time Jesus will come twice to judge mankind on earth. (3) The Holy Spirit realizes he will judge because the ruler of the world (Satan) has been subdued, meaning his power is limited. So that Satan cannot (have no right) to send down the children of God because he has been saved by the cross of Christ. Satan cannot hinder, eliminate, destroy the preaching of the gospel. God's children are victorious over the efforts of Satan. Satan is given the opportunity to do evil to man but man is empowered to fight it, so that the evil of Satan turns into a blessing for the children of God.

\footnotetext{
${ }^{12}$ George W. Peters, Teologi Pertumbuhan Gereja (Malang: Gandum Mas, 2002) 43.

${ }^{13}$ Alton Clark Scanion, Asas-asas Misiologia Alkitabiah dan untuk Masa Kini (Semarang: STBI, 1991)

${ }^{14}$ William Barclay, More New Testament Words (London: SCM Press, 1958) 134.
} $31-32$. 
So the work of "doing good" done by the believer gets the support of the Holy Spirit until the work becomes successful. The Holy Spirit guides believers to be able to do good, do good and always be good.

Principles of the Nature of the Church

The work of Missio Dei, Missio Christi and the Holy Spirit is extended to the church of God. The Church of God is the Kingdom of God where God Himself began His ministry preaching the Kingdom of God. Mark says: "The time has come, the Kingdom of God is near. Repent and believe in the gospel! " (Mark 1: 14-15). News of the kingdom continued to be headlines in His ministry; and as Luke tells us, after his resurrection, He continued to speak to the apostles "about the Kingdom of God." Thus, the news of the Kingdom of God is a focus, and even something important, the emphasis of Christ's ministry when teaching. ${ }^{15}$

The word "Church" comes from the Portuguese "Igreja", which means the same as Eklesia (Greek), which means: "called out" belongs to the Lord Jesus. The word "Eklesia" emphasizes three things: congregation (multitude), congregation (Arabic means: association, group or meeting of people), and church building.

The church has three meanings as follows: (1) those who are called out and are united to become members of the "Body of Christ" (Eph. 2: 13,19; 4: 15-16); (2) the building or place of worship (worship) from the Greek "Kurakion", means: the house of God (Dutch "Kerk"), and (3) denomination (a sect of a church that consists of several congregations). In the OT: Hebrew qahal (77 times in the OT), which was copied into ekklesia, meaning "saints". Qahal is used in connection with a particular gathering or gathering in a place, as a physical assembly and is never used to convey a discussion of the mystical association of the saints as a spiritual group of people who are geographically separated.. ${ }^{16}$ In PB: Ekklesia; congregation; gathering of saints; Christians.

Indeed, the concept of the Kingdom of God is almost unclear in the ministry of the 12 disciples. In the sermons recorded in the Bible, Peter does not use the concept, but the Epistles of II Peter 1: 1 are the only mention of the concept of "the everlasting kingdom, the kingdom of our Lord and Savior, Jesus Christ." Similarly, James wrote only once about "the kingdom which he hath promised to them that love him" (James 2: 5). The concept is not found in all three of John's letters, and is only stated in his Gospel when he directly quotes the Master (John $3: 3,5 ; 18: 36)$.

Paul developed the "Kingdom of God" and he preached about the Kingdom of God (Acts $14: 22 ; 19: 8 ; 28: 23 ; 31$ ). In his letters he explains, that now the spiritual reality of the kingdom is not a matter of food and drink, but "of righteousness, peace, and joy of the Holy Spirit" (Rom. 14:17). His moral nature, other worldly aspects of his values, nature, purpose, and realization are stated explicitly in 1 Corinthians 6: 9-10; 15:50; Galatians 5:21; Ephesians 5: 5; and II Timothy 4:18. Here, that: first, the kingdom will soon be declared. Second, the government has intricate features that are difficult to define. Third, there are special features of the government throughout the ages that are universal and qualitative - a fact that makes it more difficult to make sharp differences.. ${ }^{17}$

\footnotetext{
${ }^{15}$ Harianto GP, Pengantar Misiologi (Yogjakarta: Abdi, 2013) 32.

${ }^{16}$ John F. Walvoord, Gereja dalam Nubuatan (Surabaya: Yakin, 1984) 15.

${ }^{17}$ George W. Peters, Teologi Pertumbuhan Gereja (Malang: Gandum Mas, 2002) 47.
} 
So the church serves as a reporter for believers to do good. Servants of God not only deliver sermons, teach and share in doing good, but also set an example of doing good. Thus the church gets a picture of a life of doing good. Of course, the church is slowly becoming a life of doing good to everyone. So "doing good" is an exemplary model for human life.

\section{The Challenge of "Doing Good" from Theocentric to Christocentric"}

"Doing good" has a universal value where every human being wants to do it to the best of his life. God teaches to do good. From "doing good" everyone will be able to speak freely and even cooperate within the Theocentric sphere. From the theocentric then it is not difficult to enter the concept of Christocentric where one can be invited to share about the gospel that offers eternal salvation through Jesus Christ.

\section{Educational Implementation}

"Doing Good" in the Christian Ministry

"Doing Good" Teaching Materials

"Doing good" is a teaching material that must be applied in human life (not only Christians but non-Christians as well). Doing good is a universal teaching material. Therefore, the jal is very effective when used as a communication tool both in sharing and a more familiar level is in working together in a plural society.

With regard to the above, the Bible describes it as follows: You are good and do good; teach me Your statutes (Ps. 119: 68), "Learn to do good (Isa. 1:17), for they do not know how to do good (Jer. 4:22), God's provision (Jer. 36:11; Zech. 8:15). Furthermore, in PB it is also sharpened that "make yourself an example in doing good. Be honest and diligent in your teaching "(Titus 2: 7). So "making a temple" can be a teaching material that conveys to the example of one's life. Of course it all has to start in itself before it can be expressed to the outside. How can a person want to be an example of doing good in the midst of his society but he himself cannot appreciate doing good in himself? Doesn't "doing good" always start from within itself before it comes out?

\section{Theology of Doing Good in the Framework of Theocracy to Christocentric}

Theology "does good" in the framework of epistemology Theocracy to Christocentric which is a doctrinal territory. Speaking doctrinally means inseparable from the growth of the Christian faith and the missionary work God has given to His people. As faith is always centered on Jesus and as a missionary strives to win the lost (lost) souls.

Due to its doctrinal nature, it is sought that the concepts of "doing good" are dialogued as a greeting of the concept at the level of pluralism of religions. The dialogue is a sharing about doing good. For a Christian to do good is the teaching of the Bible itself. Rom 2:12: "All those who have sinned without the law will perish without the law; and as many as have sinned under the law shall be judged by the law. In John 18:37 it is said that Jesus came into the world that He might testify of the truth of doing good. 
God's good works are the truth based on human salvation, and it is only through Jesus Christ - man who believes in Him as Savior - that man lives in true truth. What the Bible says is the truth of God, because good deeds are God Himself, and good deeds are obedience.

Likewise Jesus is the good deed itself because Jesus is God Himself. So, if God demonstrates His good deeds to man through Jesus, it means that God also gives those good deeds in Jesus. Jesus' good deeds are that He came to be a witness of God's truth. John 1:18: "No man hath seen God at any time; but the Only Begotten of God, which is in the bosom of the Father, He hath declared Him. "Here, Jesus not only communicated the Word of God directly, but He was the Word of God Himself. He is the Christian faith.

So, the dialogue of "good deeds" eventually becomes uncompromising. When the dialogue is complete then the continuation is the partner of the dialogue will "accept" or "reject". "Accepting" means Jesus Christ is his Savior and he is guaranteed eternal life, but when he "rejects" it means that one has heard the testimony of salvation through Christ.

\section{Holistic Theology of Doing Good}

The holistic Theology of Doing Good is the area of ethics. Good deeds are what Jesus taught that believers must live in society, communicate with society, even help or share God's love with anyone. Here, Christians do good to everyone and regardless of religion. Jesus taught us to do good to fellow humans. Believers do good to people of other religions. The love that God gives to believers in Christ calls them to accept their neighbors and to invite them to know God's extraordinary "good deeds".

The process of recognizing good deeds does not mean that a person has to dress the same as a Christian, change his name to a Christian's name, or follow Christian religious rhythms. Because change does not mean manipulating human thought into evagelism, for example. Evangelism is a way of life and preaching of the Word, but change ${ }^{18}$ is a way of responding to the Word of God in a person that makes a person have a stand (attitude) that is actually true fellowship with God.

Thus, "good deeds" can be compromised as long as ethics formulated together among religious communities - are in accordance with biblical truth. These "good deeds" make Christians willing to cooperate with anyone and not see any religion to do good things help the poor, be good citizens, build state morals, go to war when the state asks for it, maintain security environment, keep the environment clean and so on. In "doing good", Christians only have the task of practicing the values of God's righteousness in truth and the values of "good deeds" by example like what Jesus did as an example of life both in doctrine and ethics. In this regard, Lumintang said that the true "doing good" (God's truth) is derived

\footnotetext{
${ }^{18}$ Ada dua tahap perubahan sebagai berikut: Tahap pertama, dalam perubahan dimulai dari persektuan yang benar dengan Allah. Perubahan ini terjadi karena undangan Allah. Di sini, orang Kristen berfungsi sebagai pendemo kasih Allah (1Kor. 3:5). Tahap kedua, Allah yang bekerja dalam diri seseorang untuk dirubahkan. Meskipun Allah yang mengundang seseorang untuk berubah tetapi sedikit orang Kristen yang mau menjadi pekerja Allah. Padahal kini sudah waktu orang Kristen mengambil hasilnya (memanen). Karena itu, sebelum orang Kristen melakukan pekerjaan Allah, ia diminta untuk berdoa terhadap kerjaan itu (Luk. 10:2). Orang Kristen itu bukan mendoakan seseorang yang akan dipanen tetapi berdoa untuk pekerja yang jumlahnya masih sedikit (Yoh. 4: 35, 37). Memanen dan mencari pekerja bukanlah suatu kegiatan sekali kerja tetapi proses yang panjang, yang harus dilakukan terus menerus.
} 
from Allah through general revelation. This truth is not the truth that brings people to know God and is not the truth that saves, but the truth that helps people to live wisely and morally.. ${ }^{19}$

\section{Good Deeds is the Mission of the Great Commission}

Although Christians want to work with anyone regardless of religion, they still live within the framework of the mission of the Great Commission - in PL God expects the Israelites to be an example of God's obedience so that other nations will come to Him (Ps. 96: $2-3,10 ; 67: 2-5)$ while in PB Christians as witnesses of God and evangelists to the whole world (Matt. 28: 18-20; Mark 16: 15-18; Luke 24: 46-49; Acts 1: 7-9; John 20: 11-23; Acts 1: $8)$.

\section{CONCLUSION}

Good deeds are commands given by God to His people. If a human being wants to be said to be good, he is obliged to do good. Because good deeds have a universal character where any religion and any belief must teach its followers to do good. Because of its universal nature, "good deeds" are very appropriate to be used in the design of multicultural theology.

The challenge of "doing good" in the dimensions of multicultural theology is: the challenge of "doing good" in theocentric, the challenge of "doing good" in Christocentric (the principle of the Incarnation, the principle of salvation, the principle of the Holy Spirit, and the principle of the naturalness of the Church) and (2) the challenge of "doing good "From Theocentric to Christocentric". "Doing good" has universal values in which every human being wants to do the best in his life. Allah teaches us to do good. From "doing good" everyone will be able to speak freely and even cooperate in the Theocentric sphere. From the theocentric, it is not difficult to enter the Christocentric concept where one can be invited to share about the gospel which offers eternal salvation through Jesus Christ.

Multicultural theology of "doing good" is a very influential implementation to lead someone into the concept of theocracy which is then sharpened to Christocentric. Here the value of the Great Commission of Jesus Christ to win people becomes real and can be implemented properly. But, of course, the work of the Holy Spirit in the believer is critical to the success of the Great Commission mission.

\section{BIBLIOGRAPHY}

Almerico, G. M. (2014). Building character through literacy with children's literature. Research in Higher Education Journal, 26 . http://www.aabri.com/copyright.html.

Baik". KBBI Offline 1.3.CD-ROM.

"berbuat Baik Bisa redakan Despresi”; http://palingseru.com/19943/berbuat-baik-bisa-redakandepresi (Diakses 20 April 2014).

"Berbuat Baik Setiap Hari"; http://kolom.abatasa.co.id/kolom/detail/motivation/672/berbuatbaik-setiap-hari.html (Diakses 20 April 2014).

${ }^{19}$ Stevri I. Lumintang, Keunikan Theologia Kristen di Tengah Kepalsuan (Batu: YPPI, 2010) 204. 
"Pengadilan Tuhan Tidak Mesti Menunggu Kiamat...";

http://hiburan.kompasiana.com/humor/2013/11/26/pengadilan-tuhan-tidak-mestimenunggu-saat-kiamat-614222.html (Diakses 14 April 2014).

Baik; kebaiakan"; Ensiklopedia SABDA;

http://alkitab.sabda.org/dictionary.php?word=BAIK,\%20KEBAIKAN (Diakses 14 April 2014).

Baik; kebaiakan"; Ensiklopedia SABDA;

http://alkitab.sabda.org/dictionary.php?word=BAIK,\%20KEBAIKAN (Diakses 14 April 2014).

Barclay, William. More New Testament Words. London: SCM Press, 1958.

Baroroh, K. (2011). Upaya meningkatkan nilai-nilai karakter peserta didik melalui penerapan peserta didik melalui penerapan metode role playing.

https://cc.bingj.com/cache.aspx?q=Baroroh\%2c+K.+(2011).+Upaya+meningkatkan+nila inilai+karakter+peserta+didik+melalui+penerapan+peserta+didik+melalui+penerapan+ metode+role+playing. \&d=4994115121783649\&mkt=en-ID\&setlang=enUS\&w=QZeteDCIMPjfD8TBBLnCDuJY2KD-sLSN

GP, Harianto.(2013). Pengantar Misiologi. Yogjakarta: Abdi.

Lumintang, Stevri I.(2010). Keunikan Theologia Kristen di Tengah Kepalsuan. Batu: YPPI.

Laila, Q. N. (2015). Pemikiran pendidikan moral Albert Bandura. 3( 1) DOI: 10.2345/jm.v2i1.740

Narvaez, D., \& Lapsley, D. K. (2014). Teaching moral character: Two strategies for teacher education; Teaching for Moral Character. DOI: 10.1080/08878730701838983

Peters, George W. (2002).Teologi Pertumbuhan Gereja. Malang: Gandum Mas.

Scanion, Alton Clark. (1991).Asas-asas Misiologia Alkitabiah dan untuk Masa Kini. Semarang: STBI.

Sudarmanto,(2014). G. Teologi Multikultural. Batu: YPPII.

Tozer, A. W. (2013) Mengenal yang Mahakudus. Bandung: Kalam Kudus.

Walvoord, (1984).John F. Gereja dalam Nubuatan. Surabaya: Yakin. 